\title{
Cumhuriyet Dönemi Türk Kadınının Modernleşmesinde Öncü Bir Kurum: İsmet Paşa Kız Enstitüsü Ankara (1928-1938) ${ }^{1}$
}

\author{
DOI: $10.26466 /$ opus.767508
}

Ayhan Dogan* - Mustafa K1lınç**

${ }^{*}$ Doç. Dr., Gaziantep Üniversitesi

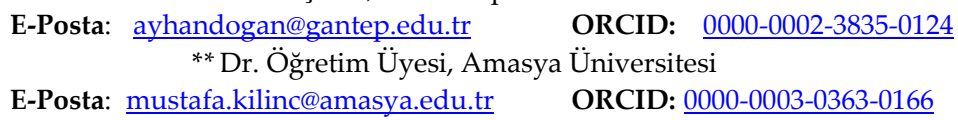

Öz

Osmanlı'da, kadınların eğitimi bağlamında Kız Sanayi Mekteplerinin değişim ve dönüşümleriyle Cumhuriyet Döneminde Kız Enstitülleri açlmıştır. Bu enstitülerden biri de -günümüzde Zübeyde Hanım Mesleki ve Teknik Anadolu Lisesi olarak faaliyet gösteren- İsmet Paşa Kız Enstitüsü'dür. Bu enstitünün temel misyonu; yeni Türk kadınlarna modern dünyadan örnekler vermek için kurulmuş bir sanat ve kültür müessesesi olmasıdır. Bu kurum, yabancı bilim insanı Omar Buyse'nin önerisiyle İsmet Paşa Kız Enstitüsü olarak 1928 eğitim öğretim yılında faaliyetine başlamıştır. Enstitü, tarihsel süreçte birçok isim değişikliğine uğrayarak günümüzde Zübeyde Hanım Mesleki ve Teknik Anadolu Lisesi ismini almıştır. Okulun temel misyonu çağdaş Türk kadını yetiştirme projesi olmuştur. Öte yandan İsmet Paşa Kız Enstitüsü bazı komşu ülkelere örnek bir eğitim kurumu olabilecek düzeyde bir kurum olarak faaliyet göstermiştir. İsmet Paşa Kız Enstitüsü, sadece Doğu ülkelerinden değil Batı ülkelerinden de kişi ve kurumların dikkatini çekmiştir. Amerika Birleşik Devletleri'nin Büyükelçisi Charles H. Shenill, 5 Temmuz 1932'de, okulu ziyaret etmiş, izlenimlerini ülkesindeki sorumlu bakana bildirmiştir. Bu araştırmanmn amacı; İsmet Paşa Kız Enstitüsü'nün Türk kadınının modernleşmesindeki katkısina vurgu yaparak üstlendiği rolü ortaya çıkarmaktır. Tarama modeliyle gerçekleştirilen bu araştırma, İsmet Paşa Kız Enstitüsü'nün Türk kadınmmn modernleşmesindeki yeri inceleyerek söz konusu olguya hangi açlardan katkı sunduğunu ortaya koyan betimsel bir araştırmadır. Bu araştırmada nitel veri toplama tekniklerinden biri olan doküman incelemesi kullanılmış ve elde edilen veriler içerik analizi yöntemiyle incelenmiş̧tir. Araştırmada veri toplama aracı olarak incelemeye alnan veriler; T.C. Cumhurbaşkanlı̆̆ı Devlet Arşivleri Başkanlığı Cumhuriyet Arşivi fonlarında yer alan kaynaklar, dönemin gazeteleri, konu ile ilgili telif eserlerle lisansüstü tezlerden temin edilmiştir. Eldeki veriler anlam bütünlüğü açısından tasnif edilerek çalışma biçimlendirilmiştir.

Anahtar Kelimeler:

Zübeyde Hanım Mesleki ve Teknik Anadolu Lisesi, İsmet Paşa Kız Enstitüsü, Modernleşme, Türk Kadını.

\footnotetext{
${ }^{1}$ Bu Araştırma: 6-8 Eylül 2018'de (International Learning, Teaching and Educational Research Congress Amasya) Sözlü Bildiri Olarak Sunulan Türk Kadının Modernleşmesinde Ankara Zübeyde Hanım Kız Teknik ve Kız Meslek Lisesinin Yeri Adlı Araştırmanın Genişletilmiş Halidir)
} 


\title{
An Outstanding Institution In The Modernization of Turkish Women During The Republic Period: İsmet Paşa Girls' Institute-Ankara- (1928-1938)
}

*

\begin{abstract}
In the Ottoman Empire, Girls' Institutes were opened after the transformation of Girls' Industrial Schools in terms of women education. One of these is İsmet Pașa Girls' Institute, today serves as Zübeyde Hanim Vocational and Technical Anatolian High School. The importance of this school was that it was a cultural and art center founded to display the examples from the world to the Turkish women. This school started to teach as İsmet Paşa Girls' Institute thanks to the suggestions of the foreign scholar Omar Buyse in 1928. The institute is called as Zübeyde Hanım Vocational and Technical Anatolian High School even though it had undergone several changes with its name. The basic mission of this institute was to educate the contemporary Turkish Woman prototype. Moreover, it drew attention of individuals and institutions from the West countries while functioning as a pioneer educational institution which could be taken as an example. İsmet Paşa Girls' Institute drew attention of the individuals and institutions from the east countries as well as the ones in the west. Charles H. Shenill, A US Ambassador, visited the school in the fifth of July, 1932 and shared his observations with the related minister in his own country. The purpose of this study was to reveal the role of Ismet Paşa Girls' Institute, drawing attention to its contribution to the modernization of Turkish women. This study, designed as a survey research, is a descriptive one that unearths what contributions made by the Ismet Paşa Girls' Institute to the modernization of Turkish women. In this study, the data sources were documents and the obtained documents were analyzed through content analysis. The data sources can be listed as: sources in the Presidency of the Turkish Republic Directorate General of State Archives, related newspapers, copyrighted sources, and dissertations. The related data were classified based on the theme in the study
\end{abstract}

Keywords: Zübeyde Hanım Vocational and Technical Anatolian High School, İsmet Paşa Girls' Institute, Modernization, Turkish Woman 


\section{Giriş}

Modern kelimesi; çağcl, çağdaş ve yeni anlamlarına gelmektedir. Modernleşme ise; Batı Avrupa'da sanayi inkılabıyla ortaya çıkan ekonomik, sosyal ve siyasi gelişmeleri ifade eden bir kavramdır. Genel anlamda modernleşmenin dört aşamasından bahsedilmektedir. Bunlar 1.Sanayileşme ve ekonomik gelişmişlik, 2. Bilgiye, ahlaka ve sanata bakış açısı, 3. Geleneksel toplum anlayışından farklılaşıp bireyin kendini yöneten birey olması, 4 . Ulus devlet olma ve demokratik süreçleri yaşama aşamasıdır. (Kurtdaş, 2012, s.101-102) Türk kadınının modernleşmesinde Cumhuriyet döneminde Ankara' da açlarak faaliyet göstermiş bir kurum olan İsmet Paşa Kız Enstitüsünün yeri bağlamında bu eğitim kurumu; modernleşme unsurları ekseninde 1. Sanayileşme ve ekonomik gelişmişlik noktasında okul fabrika gibi üretim faaliyetinde bulunarak, 2. Bilgiye, ahlaka ve sanata bakış açısı çizgisinde düzenlemiş oldukları sergilerle sanat anlayışına katkılarıyla 3. Geleneksel toplum anlayışından farklılaşıp bireyin kendini yöneten birey olması noktasında bu eğitim kurumu yeni Türk kadınına model olması bağlamında, 4 . Ulus-devlet olma ve demokratik süreçleri yaşama aşamasında ise toplumda erkeklerle aynı haklara sahip olma noktasında Türk kadınının modernleşmesinde etken rol oynayan eğitim kurumlarından biri olmuştur.

Bu bağlamda Avrupa'da Coğrafi keşifler, Rönesans, Reform, Sanayi ink1labı ile birlikte ortaya çkan "aydınlanma dönemi" nde elde edilen kazanım, değer ve bunun etkileri, Osmanlı Devleti'nde 18. yüzyıldan itibaren görülmeye başlamış; Tanzimat Dönemi ile birlikte büyük bir hız kanmıştır. Meşrutiyet dönemlerinde artan modernleşme olgusu, akabinde Türkiye Cumhuriyeti Devleti Dönemi'nde de devam etmiş ve etmektedir. (Kurtdaş, 2012, s.112) Bu minvalde kadın eğitimi konusunda özellikle Osmanlı Devleti'nde 2. Meşrutiyet Döneminde ciddi tartışmalar yaşanmıştır (Karagöz,Şanal,2015, s.679). Bu dönemde kadınların okuma yazma bilmelerinin yanında; yemek yapma, dikiş dikme ve nakış yapma gibi hünerlerinin de gerektiği (Karagöz, Şanal,2015, s.680,681) ve kadınların da erkekler gibi sanat sahibi olması gerektiği ifade edilmiştir( (Karagöz ve Şanal,2015,685). Bu noktada Osmanlı Devleti'nde eğitim alanındaki modernleşme çalışmalanı özetle askeri okullarla başlamış kız rüştiyelerinin açılmalarıyla devam etmiştir. Mithat Paşa za- 
manında kurulan 1slahhaneler, sanayi mekteplerine dönüştürülmüş; kız sanayi mekteplerinin Cumhuriyet Döneminde yeniden yapılandırılmasıyla da kız enstitülerinin temeli atılmıştır.

Cumhuriyet döneminde Türkiye'ye davet edilen yabancı bilim insanlarından biri olan John Dewey'in teklifi üzerine açılmaya başlayan ve kadınların eğitimine yönelik olarak faaliyet gösteren kız enstitülerinden ilki, İsmet Paşa Kız Enstitüsü'dür. 1928 yılında, Maarif Vekaleti'ne bağlı olarak kurulan bu enstitüye İsviçreli Omar Buyse'nin önerisi üzerine İsmet Paşa Kız Enstitüsü ismi verilmiştir. (Kurtdaş, 2012, s.112) Buyse, İsmet Paşa Kız Enstitüsü ile ilgili olarak 11 Mayıs 1928'de dönemin vekillik makamına bir rapor sunmuştur(Karagöz,2019,s.304).Bu raporda enstitü projesinin hükümet merkezinin ihtiyaçlarını karşılayacağını belirterek açılacak enstitünün de ilk seneden itibaren kaç öğrenci ve kaç şubesinin olabileceği hakkında da bilgiler sunmuştur(Karagöz,2019,s.306). Enstitü, ilk olarak 1928 eğitim öğretim yılında sadece 5 öğrenci ile Çocuk Esirgeme Kurumu'na ait bir binada faaliyete başlamış; aynı eğitim öğretim yılının sonunda öğrenci sayısı 28'e ulaşmıştır. (URL 1) 1930-1931 yılında ise yeni binasına taşınmıştır. (Alpagut, 2005, s.212) Bu yeni binanın planı, Alman asıllı Ernst Egli tarafından yapılırken inşaatı da bir Türk firması tarafından tamamlanmıştır. (Cevizliler ve Cevizliler, 2004, Sayı:9, s. 183) 1931 yılında okul, Fransız asıllı bir müdire tarafından yönetilirken 1932'den itibaren Türk bir yönetici olan Münir Hayri Bey tarafından idare edilmeye başlamıştır. (Cevizliler ve Cevizliler, 2004, s. 183) Okulun açldığ ilk yıllarda, bu eğitim kurumu üç farklı okulu bünyesinde barındırmıştır. Bunlar: İsmet Paşa Kız Enstitüsü, Kız Teknik Yüksek Öğretmen Okulu ve Akşam Kız Sanat Okulu'dur. (Ulus, 1936, s.5)

İsmet Paşa Kız Enstitüsü, Cumhuriyet Döneminin ilk Kız Enstitüsü (URL2) olmakla beraber Başkent Ankara'da açlmış olması dolayısıyla Türk kadınının toplumsal dönüşümü açısından oldukça önemli bir yere sahip olmuştur.

Bu eğitim kurumunun tarihi gelişim sürecine bakıldığında ise okulun, farklı dönemlerde değişik isimlerle eğitim öğretime devam ettiği görülmektedir. (Kılınç, 2017, s.15-16, s.39-41)

1935 yılında kız sanat okullarına öğretmen yetiştirmek amaciyla, bu enstitü içinde ayrı bir kurum olarak Kız Teknik Yüksek Öğretmen Okulu açımıştır. Bundan dolayı kurumun ismine ekleme yapılarak kurumun adı, Ismet Paşa Kız Enstitüsü ve Kız Teknik Yüksek Öğretmen Okulu olmuştur. Okul, bu 
isim altında eğitim öğretime devam ederken 1969 yılından sonra öğretmen yetiştiren kısmının yeni binasına taşınması sonucunda Maltepe Kız Enstitüsü ile birleştirilerek Zübeyde Hanım Kız Enstitüsü olarak adı değiştirilmiştir. 19791980 eğitim öğretim yılında Ankara Olgunlaşma Enstitüsü binası içinde bulunan Ankara Kız Meslek Lisesi bu okula aktarılınca; okul, Zübeyde Hanım Kız Meslek Lisesi adını almıştır. 1991-1992 yılında Teknik Lise; 1992-1993 yılında Anadolu Kız Meslek Lisesi hüviyetini taşımaya başlayan bu okul, 1994-1995 yılında Zübeyde Hanım Meslek Lisesi adını almıştır. 2007 yılında Zübeyde Hanım Kız Teknik Anadolu Kız Meslek ve Kız Meslek Lisesi; 2008 yılında Zübeyde Hanım Kız Teknik ve Kız Meslek Lisesi ismini almıştır. Son olarak ise 2014 y1lında Zübeyde Hanım Mesleki ve Teknik Anadolu Lisesi adını almış olan bu okul eğitim öğretim hayatına halen bu isimle devam etmektedir.

Böyle bir tarihsel dönüşüme sahip olan İsmet Paşa Kız Enstitüsünde; öğrenim süresi iki kısma ayrılmış durumdaydı. Beş yıllık öğrenim süresinde okulların birinci kısmına ilkokul mezunları, ikinci kısmına ise ortaokul mezunları kabul edilmekteydi. İlkokul mezunlarının öğrenim süresi beş yıl iken ortaokul mezunu olan öğrenciler için bu süre iki yıldı. (Kılınç, 2013, s.267) Bu eğitim sürecinde uygulamalı eğitimle beraber öğrencilere, eğitim öğretim faaliyetlerinde toplumu ve çevreyi araştırma-geliştirme gibi beceriler de edindirilmiştir. (Akın, 2011 s.3) Bununla birlikte -diğer kız enstitülerinde olduğu gibi- genel teorik bilgi verilmekle beraber; öğrencileri özellikle becerikli, marifetli, bilgili bir anne ve ev kadını olarak topluma kazandırmak temel amaçtı. (Gök, 1999, s. 242) Nitekim bu okullara, enstitü denilmesinin temel nedeni bu olmuştur. (Akın, 2011, s.40) Zira gelişmekte olan ülkelerde kadınlar, toplumu modernleştirme projelerinin merkezindeydi. (Akşit, 2005, s.146) Bu noktada Türkiye'de enstitülerin temel misyonları, Cumhuriyet'in yeni ideolojisini yaymak ve sonraki kuşaklara aktarmak olmuştur. (Akşit, 2005, s.144)

İsmet Paşa Kız Enstitüsü'nün kuruluş aşamasında Meslek ve Ticaret Kısmı Şubesinde 1-Biçki ve Dikiş, 2-Çamaşır ve Nakış, 3-Moda ve Çiçek ve 4-Ticaret ve Lisan bölümleri; yüksek kısım şubesinde ise 1- Kadın Sanatlar, 2- ticaret ve Katiplik, 3- Öğretmen, 4- İçtimai Hizmetler, 5- Hasta Bakıcllk bölümleri yer almıştır. (E. Cevizliler ve N. Cevizliler, 2004, Sayı:9, s. 184-185) Enstitünün 1939 yılında uygulanan haftalık ders programına bakıldığında; söz konusu bölümlerde beş yıllık öğrenim sürecinde teorik ve uygulamalı bir şekilde okutulan genel dersler şunlardır: (Kılınç, 2013, s. 43) Türkçe, Yurt Bilgisi, Coğ- 
rafya, Tarih, Matematik, Fizik, Kimya, Yabancı Dil, Jimnastik, Muzik, El Yazısı, Askerlik, Tabiat ve Sağglk Bilgisi, Defter Tutma. Okutulan genel mesleki derslere bakıldığında ise Dikiş Başlangııı, Nakış, Resim ve Tezyini Resim, Yemek Pişirme, Ev İdaresi, Çamaşır Yıkama, Temizlik, Ütü, Kola, Çocuk Bakımı, Hıfzısıhha ve Ev İdaresine Tatbiki derslerinin yer aldığı görülmektedir. (Kılınç, 2013, s. 43)

Bu araştırmanın amacl; İsmet Paşa Kız Enstitüsü'nün Türk kadınının modernleşmesindeki katkısına vurgu yaparak üstlendiği rolü ortaya çıkarmaktır. Okulun Türkiye Cumhuriyeti Devleti'nin ilk kız enstitülerinden biri olması ve başkent Ankara'da açılarak faaliyet göstermiş olması okula ayrı bir önem kazandırmıştır. Okul kız enstitülerinin misyonu olan Cumhuriyet değerlerini topluma kazandırma bakımından önemli bir rol üstlenmiştir. $\mathrm{Bu}$ bağlamda gerçekleştirilen araştırmada, okulun Türk eğitim tarihindeki önemi ve özellikle çağdaş Türk kadınını yetiştirmedeki özelliği ifade edilmeye çalışılmıştır. Bu amaç doğrultusunda yapılan bu araştırmada, esas olarak, şu araştırma sorusuna cevap verilmeye çalışılmıştır:

- “1928-1938 yılları arasındaki faaliyeti bağlamında, İsmet Paşa Kız Enstitüsünün Türk kadının modernleşmesindeki yeri ve önemi nasıldır?

\section{Yöntem}

Tarama modeliyle gerçekleştirilen bu araştırma, İsmet Paşa Kız Enstitüsü'nün Türk kadınının modernleşmesindeki yeri inceleyerek söz konusu olguya hangi açlardan katkı sunduğunu ortaya koyan betimsel bir araştırmadır. Bu araştırmada nitel veri toplama tekniklerinden biri olan doküman incelemesi kullanılmış ve elde edilen veriler içerik analizi yöntemiyle incelenmiştir. Araştırmada veri toplama aracı olarak incelemeye alınan veriler; T.C. Cumhurbaşkanlığı Devlet Arşivleri Başkanlığı Cumhuriyet Arşivi fonlarında yer alan kaynaklar, dönemin gazeteleri, konu ile ilgili telif eserlerle lisansüstü tezlerden temin edilmiştir. Eldeki veriler anlam bütünlüğü açısından tasnif edilerek çalışma biçimlendirilmiştir.

\section{Bulgular}

Cumhuriyet Döneminde Türk kadının modernleşmesi olgusunu konu edinen bu araştırmada; İsmet Paşa Kız enstitüsünün 1928-38 yılları arasındaki 
faaliyetlere ilişkin aşağıda yer alan bulgular; modernleşmenin temel boyutlarından olan sanayileşme ve ekonomik gelişmişlik, bilgiye, ahlaka ve sanata bakış açısı, geleneksel toplum anlayışından farklılaşıp bireyin kendini yöneten birey olması, ulus devlet olma ve demokratik süreçleri yaşama aşamaları açısından incelenmiştir.

Bu çerçevede, İsmet Paşa Kız Enstitüsü ile ilgili dönemin basılı kaynakları arasında bulunan gazeteler incelendiğinde; Ulus Gazetesi'nde farklı tarihlerde yayımlanan bazı haberler dikkat çekici bir değerlendirme sunmaktadır:

- “Kız Enstitüsü gerek yapısı gerek öğretme usulleri gerek öğretim kadrosu bakımından memleketin övüneceği ve pek az yabancı memleketlerde eşine rastlanan nitelikte bir kurumdur". (Ulus, 1935, 15, Haziran, s.3)

- IIsmet Paşa Kız Enstitüsü: Yeni Türk kadınlığına güzel örnekler vermek için kurulmuş bir sanat ve kültür müessesesidir". (Ulus, 1936, 26, Ağustos, s.5)

Gazete haberindeki bu söylemler ile söz konusu enstitünün tüm yurttaki kadınlara rol model olduğuna ve modern bir eğitim kurumu olduğuna vurgu yapilmıştır.

Ayrıca enstitüyle ilgili bir başka gazete haberinde, bu eğitim kurumunun tüm Türk kadınları için önemi şu cümlelerle ifade edilmiştir:

- "Seneler geçtikçe inkişaf eden ve bütün yurd kadınlı̆̆ına alakadar eden bu kaynak üzerinde ana ve babalarm dikkat ve alakalarm çekeceğiz". (Ulus, 1936, 26 Ağustos, s.5)

Yukarıda yer alan gazete haberine göre; enstitünün, eğitim öğretim faaliyetleri yönünden geliştiği ve okulu tercih eden öğrenci sayısının artırılmasının hedeflendiği anlaşılmaktadır.

Türkiye'de Olgunlaşma Enstitülerinin de temelini oluşturan eğitim kurumlarından biri olan İsmet Paşa Kız Enstitüsü'nün, bir yandan kızların sanat eğitimi ile meslek edinmelerini sağlarken diğer taraftan Ankara'da modanın oluşumuna da öncülük ettiği belirtilmiştir. (Arı̆̆, 2011, s.3) Bu tespite paralel olarak dönemin bir gazetesinde çıkan haberde; enstitünün, bu yönüyle " $A n$ kara kadınlarnnn güzel giyinme ve zarifliği üzerinde etki eden bir eğitim kurumu olduğuna" vurgu yapılmıştır. (Ulus, 1935, 10, Nisan, s.5) Nitekim İsmet Paşa Kız Enstitüsü öğrencilere sadece dikiş dikmeyi öğretmemiş; düzenlenen sergi, defile gibi etkinliklerle başta Ankara olmak üzere ülkede batılı giyim tarzının yaygınlaşmasına öncülük etmiştir. 
Bunlarla birlikte, okulun ilk yöneticilerinden biri olan Münir Bey, “...okul modanın öncülü̈̆̈̈nü gerçekleştirirken bir taraftan da fabrika gibi çalışmıştır..." ifadesini kullanmıştır. (Hayri Münir, "Üç Mektep Üç Sergi", Ulus, 1 Temmuz 1936, s.41936, s.5) Bu ifadeden hareketle okulun, özellikle kumaş ve elbise üretiminde önemli bir fonksiyonu yerine getirdiği anlaşılmaktadır.

Ulus Gazetesinde yayımlanan bir diğer haberde; taşradaki Türk kadınlarmın eğitimi için okulun bir de pansiyon kısmı bulunduğu, bu pansiyonda ücretli kalan öğrencilerin yıllik 200 lira ücret ödediği, bu ücreti -ilki okula kayıt esnasinda olmak üzere- ̈̈ç taksit halinde alındığ okuyan kardeşi bulunanlara \%15'lik bir kardeş indirimi yapıldığ bilgisi verilmiştir. (Ulus, 1936, 26, Ağustos, s.5) Bu bilgilerden hareketle söz konusu okulun taşradaki kadınların eğitimine destek olmak suretiyle eğitimde fursat eşitliği sağlamaya çalıştığl; memur ve kardeş indirimi gibi uygulamalarla vatandaşları eğitime teşvik etmeye çalıştı̆̆ söylenebilir.

Modernleşmenin temel aşamalarından biri olan sanata bakış açısından düşünüldüğünde; İsmet Paşa Kız Enstitüsü'nde, bir taraftan eğitim faaliyetleri yerine getirilirken diğer taraftan da öğrencilerin ürettiklerini tanıtmak için geleneksel olarak yılda bir kez sergi faaliyetleri düzenlenmiştir. Okulun düzenlediği sergiler için yurt dışından modayı yakından takip eden yabancı öğretmen ve şefler davet edilmiştir. (Ulus, 1936, 5 Mayss, s.5) Bunlardan biri 1936 yılında Paris'ten getirilen ve moda üzerine 25 yıllık mesleki tecrübeye sahip eğitim şefi Ms. Pilsen'dir. (Ulus, 1936, 4 Mayıs, s.2) Düzenlenen moda gösterileri hayranlık uyandırdığı gibi etkinlikler kapsamında sunulan batı tarzı dans gösterileri (vals vb.) izleyiciler tarafından övgüyle karşılanmıştır. ("Maarif Vekilliği Dergisi" Sayı: 21-22, 1939, s. 169-171.; Ulus, 1935, 16, İlkkanun (Ekim), s.4) Nitekim Enstitü'nün düzenlemiş olduğu sergileri gezen yabanc1 misafirler "Böyle eğitim kurumlarn gelişmiş ülkelerde bile azdır" şeklinde beğeni cümleleriyle duygularını ifade etmişlerdir. (Münir, "Ulus”, 1936, s.5) Genel anlamda değerlendirildiğinde; okulda gerçekleştirilen bu tür etkinliklerle Türk kadınının devrin modasını takip edebilmesine uygun ortam sağlanmakla birlikte, Türk kadınının modernleşme serüvenine farklı zeminde bir katkı yapılmıştır.

İsmet Paşa Kız Enstitüsü, Türk kadınının modernleşmesinde öncü bir eğitim kurumu olarak, uluslararası eğitim anlayışına sahip, Batı tarzı eğitim öğretim metotlarını benimsemiş, model ve vizyoner bir kurum olarak faaliyet 
göstermiştir. Bu minvalde okulun müdürlerinden olan Münir Bey'in okulla ilgili değerlendirmeleri şöyledir:

"İsmet Paşa Kız Enstitüsü bir Türk müessesesidir fakat yalnız bizim değil milletler arası adı sayılan terbiye müessesesi arasına girmiştir." Diğer yandan enstitünün; Atatürk'ün "Kadın varlığı ulusun bin bir noktadan temelidir..." diye tavsif ettiği Türk kadınını, yeni şartların ihdas ettiği vazifelere göre forme etmekte ön ayak olacağ 1 düşünülmüştür. Buradan mezun öğrenciler Yeni Türkiye' nin ilk özlü sanat hocaları olmuştur. (Münir, 1936, s.5)

Ayrıca okulun uluslararası eğitim anlayışına sahip olduğunun en önemli kanıtlarından biri, Belçika gibi özellikle mesleki ve teknik eğitim alanında dönemin gelişmiş ülkelerinden bu okula öğretmen görevlendirilmiş olmasıdır. (Başbakanlık Cumhuriyet Arşivi, (BCA), Fon Kodu: 301000, Kutu No: 261, Dosya Gömleği No: 762, Sıra No: 24, Tarih:17.05.1932) Nitekim 1932' de 65 öğretmenden dördü Belçika ve Avusturyalıdır. (Sezer Arı̆̆, agm., s.8) Yurt d1şından getirilen bu öğretmenlerden daha uzun süre yararlanmak için zaman zaman öğretmenlerin görev süreleri uzatılmıştır. (BCA, Fon Kodu: 30-18-02, Kutu No: 28, Dosya Gömleği No: 39, Sıra No: 9) Bununla birlikte enstitüdeki Türk öğretmenlerden bazıları, alanlarıyla ilgili gelişmeleri yakından takip edip kendilerini geliştirmeleri için yurt dışına gönderilmiştir. (BCA, Fon Kodu: 30-18-01-02, Kutu No: 47, Dosya Gömleği No: 52, Sıra No: 4)

Öte yandan İsmet Paşa Kız Enstitüsü bazı komşu ülkeler için de örnek bir eğitim kurumu olabilecek düzeyde bir kurum olarak faaliyet göstermiştir. Nitekim dönemin İran Şahı Rıza Pehlevi, Türkiye'ye (10 Haziran/07 Temmuz) 1934 yılında gerçekleştirdiği bir ziyaretinde (Makki,1985, s.157)2, okul

\footnotetext{
${ }^{2}$ Rıza şah 1934 yılında 17 kişiden oluşan bir heyetle Türkiye'yi ziyaret etti. Tebriz, Hoy ve Maku şehirlerinden geçerek Türkiye topraklarına vardılar. Kars, Erzurum, Trabzon ve Samsun yolu üzerinden Ankara'ya geçiş yaptılar. Rıza şah ve heyeti 38 gün içinde Türkiye'nin çeşitli yerlerinden ziyaret ettiler. Ancak ziyaret ettikleri en önemli yerler; halk partisinin binası, Cumhuriyet, Dışişleri ve Meclis binaları, Harp okulları, Dardanel (Çanakkale) ve Bosfor boğazlarının tahkimatı, Osmanlı Emperatorlerinin sarayları, Hipodrom, Kız ve Erkek İci Okulları, Musiki Okulları olarak kayıtlanmıştır. Bu ziyaret Rıza Şah'ın düşüncesinde derin etki yaratmıştır. O dönemde Iran'ın Türkiye Büyükelçisi olan Mirza Sadık Kan Mosteşar al-Dawlah, Rıza şahın bu etkilenmeden dolayı sarf ettiği sözleri şöyle anlatmıştır; Bir gece Rıza şah muhteşem bir resmi ziyafetten döndükten sonra sabaha kadar uyuyamadı ve odasında sürekli yürüyerek düşünüyordu ve bazen yüksek sesle: Garip! (Tuhaf), Garip! Diyordu. Bende odanın bir köşesinde durmuştum. Rıza Şah beni fark edince dedi: "Sadık, Dürüst olmak gerekirse Türklerin bu kadar ilerlediklerini hayal etmiyordum. Avrupa medeniyetine ulaşmada büyük çabalar sarf etmişler ve çok ilerlemişlerdir. Şimdi çok geride kaldığımızı anladım. Özellikle kadınların eğitimi ve ilerlemesi için zaman kaybetmeden hızlıca işlemlere başlamalıyız"
} 
gezileri kapsamında İsmet Paşa Kız Enstitüsü'nü gezerek bu okulu çok beğenmiştir. Bu eğitim kurumunun aynısının Tahran'da da yapılmasını istemiştir. Tahran'ın en işlek ve güzel caddesinde inşa edilen okulun, rengi bile aynı olmuştur. Açılışını bizzat İran Şahı'nın kendisinin yaptığı ve Hüneristan-1 Duhteran (URL 3) ${ }^{3}$ ismi verilen 200 yataklı bu okulda, Türkiye'deki İsmet Paşa Kız Enstitüsü eğitim programı aynen uygulanmıştır. (Soroşiyani, Daniel, And Bijan Shafei, 2008, s.42); BCA, Fon Kodu: 30.18.02, Kutu No: 28, Dosya Gömleği No: 39, Sıra No: 9, Tarih: 1938.11.03; Kılınç, 2016, s.234) ${ }^{4}$

İsmet Paşa Kız Enstitüsü, sadece Doğu ülkelerinden değil Batı ülkelerinden de kişi ve kurumların dikkatini çekmiştir. Nitekim Amerika Birleşik Devletleri'nin Büyükelçisi Charles H. Shenill, 5 Temmuz 1932'de, okulu ziyaret etmiş, izlenimlerini ülkesindeki sorumlu bakana bildirmiştir. Büyükelçi, okulun çağdaş bir eğitim kurumu olduğunu söylemiştir. (E. Cevizliler ve N. Cevizliler, 2004, Sayı:9, s.181,185,186)

\section{Sonuç}

Günümüzde Zübeyde Hanım Mesleki ve Teknik Anadolu Lisesi olarak faaliyetine devam eden İsmet Paşa Kız Enstitüsü, Cumhuriyet dönemi Türkiye'sinde çağdaş Türk kadını yetiştirme anlamında örnek bir eğitim kurumu olarak Türk eğitim tarihinde yerini almıştır. İsmet Paşa Kız Enstitüsü, Cumhuriyet Dönemi kız meslek ve teknik eğitimi alanında açlan ilk eğitim kurumu olma özelliğini taşımaktadır. Yeni kurulan devletin başkentinde dönemin en işlek bir caddesinde gerek görkemli ve renkli mimari yapısıyla gerekse de eğitim öğretim faaliyetlerinde kız çocuklarına yönelik olarak bütün

\footnotetext{
${ }^{3}$ Birinci Pahlevi Dönemi'nde (Rıza Şah) Serheng Sehayi Caddesi, Tahran, Iran 'da خيابان سرهنگ سخائ (M.

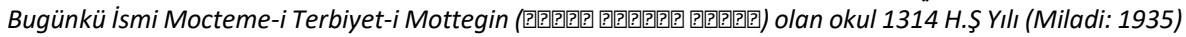
1317 H.Ş Yılı (Miladi: 1938) Mimar Vartan Hovanessian tarafindan yapılmıştır;

${ }^{4}$ Bu okulla ilgili yabancı kaynaklarda da şu ifadelere rastlanılmıştır; 1938 yılında Rıza Şah'ın huzurunda okulun açılışı yapıldı. Okula müdür olarak atanan Meryem Erdelan, açılış esnasında sunduğu raporda bu okulda, 200 kı öğrenciye eğitim verileceği, öğrenim süresinin 3 yıl olduğu ve öğrencilerin hayatın gereksinimlerini karşılamak için ihtiyaç duydukları alanlarda ve yetenekleri doğrultusunda derslere gireceklerini vurgulamıştır. Bu okulun müfredatında aile yönetimi, ev ekonomisi, aşşılık, pastacılık, terzilik, hemşirelik ve el işleri şubelerinin olduğunu ifade etmiştir. Bu okulda, özellikle fakir ve yetim kızların eğitim göreceği ifade edilmiştir (Melek Zade Elham. Pahlevi Döneminde Kadınların Resmi Tarihçesine Bir Bakış, 2013, s.98). Günümüzde ise, okul kız ve erkek bölümlerine ayrılarak aynı amaç doğrultusunda, yetim öğrencilerin iyi yetiştirilmesine katkı sağlayarak faaliyetine devam etmektedir.
} 
meslek alanlarıyla ilgili uygulama ağırlıklı eğitim öğretim faaliyetleri gerçekleştirmesi ve modern eğitim sunması bakımından dikkat çekmiştir.

Okul geleneksel olarak düzenlediği moda gösterileriyle hem yurt içi hem yurt dışı takdir kazanmıştır. Hatta okul tarafından modanın başkenti olarak kabul gören Paris'te dahi defile düzenlenmesi, modernleşme adına Türk kadınının değişim göstergelerinden biridir. Bu enstitüde hem Türk hem de yabancı öğretmenlerin çalışmış olması ve okulun ilk yıllarında yabancı eğitimcilerin de okul yöneticiliği yapmış olması okulun eğitim öğretim faaliyetlerinin evrensel düzeyde gelişmiş olduğunu göstermesi açısından önemlidir. ${ }^{5}$

Okula başta Türkiye Cumhuriyeti Devleti'nin kurucusu Mustafa Kemal Atatürk olmak üzere yabancı ülkelerden de üst düzey ziyaretler gerçekleştirilmiştir. Bu bağlamda, bazı yabancı ziyaretçilerin okula hayranlığının göstergesi olarak okulun tıpkısını kendi ülkelerinde inşa ettirmeleri ve $\mathrm{ABD}$ gibi gelişmiş bir ülkenin temsilcisinin okulla yakından ilgilenerek okulla ilgili özellikleri rapor etmesi Cumhuriyet Dönemi eğitim alanındaki gelişmeleri ifade etmesi bakımından önemli bir durumdur.

Bu okulda, Türk kadının bir taraftan iyi eş, iyi öğretmen, çağdaş anne, kültürel yönden kendini geliştirmiş, sağlam kişilik sahibi bireyler olarak yetiştirilmesi istenirken; diğer taraftan ise idealist, özgür, Cumhuriyet' in temsilcisi ve Cumhuriyet değerlerinin koruyucusu olan modern ve örnek bireyler olarak yetiştirilmesinin hedeflendiği anlaşılmaktadır.

${ }^{5}$ Okullarda ve kurumlarda eğitimin kalitesini değerlendirirken; yabancı öğrenci, yabancı öğretmen ve yabancı yöneticinin bulunması artı değer olarak düşünülmektedir. 


\title{
EXTENDED ABSTRACT
}

\section{An Outstanding Institution In The Modernization Of Turkish Women During The Republic Period: İsmet Paşa Girls' Institute-Ankara- (1928-1938)}

\author{
Ayhan Doğan - Mustafa Kılınç \\ Gaziantep Üniversitesi, Amasya Üniversitesi,
}

The concept 'modern' refers to contemporary, up-to-date, and new. Modernization, on the other hand, is considered as a concept that represents the economical, social, and political developments triggered by the Industrial Revolution in the West Europe. Modernization typically consists of four steps: 1. Industrial and economical development, 2. Perspectives on knowledge, ethics and art, 3. Being an independent individual rather than dependent on the traditional society, and 4. Being a nation state and undergoing the democratic processes. The modernization process of Turkey started in the Tanzimat Reform Era in which the modernization in the Ottoman Empire had also stepped up, and continued during the 1st Constitutional Period, 2nd Abdulhamit Period and the 2nd Constitutional Period. Modernization in Turkey's educational history started with the military schools, girls' middle schools etc. In the Ottoman Empire, Girls' Institutes were opened after the transformation of Girls' Industrial Schools in terms of women education. One of these is İsmet Paşa Girls' Institute, today serves as Zübeyde Hanım Vocational and Technical Anatolian High School. The importance of this school was that it was a cultural and art center founded to display the examples from the world to the Turkish women. This school started to teach as İsmet Paşa Girls' Institute thanks to the suggestions of the foreign scholar Omar Buyse in 1928. The institute is called as Zübeyde Hanım Vocational and Technical Anatolian High School even though it had undergone several changes with its name. The basic mission of this institute was to educate the contemporary Turkish Woman prototype. Moreover, it drew attention of individuals and 
institutions from the West countries while functioning as a pioneer educational institution which could be taken as an example. İsmet Paşa Girls' Institute drew attention of the individuals and institutions from the east countries as well as the ones in the west. Charles H. Shenill, A US Ambassador, visited the school in the fifth of July 1932 and shared his observations with the related minister in his own country.

The purpose of this study was to reveal the role of İsmet Paşa Girls' Institute, drawing attention to its contribution to the modernization of Turkish women. This study, designed as a survey research, is a descriptive one that unearths what contributions made by the İsmet Paşa Girls' Institute to the modernization of Turkish women. In this study, the data sources were documents and the obtained documents were analyzed through content analysis. The data sources can be listed as: sources in the Presidency of the Turkish Republic Directorate General of State Archives, related newspapers, copyrighted sources, and dissertations. The related data were classified based on the theme in the study.

İsmet Paşa Girls' Institute, which was opened in line with the recommendations of John Dewey, one of the foreign scientists invited to Turkey during the first years of Republic of Turkey, was the first one that addressed the education of women. The institute, which was affiliated to Maarif Vekaleti (Ministry of Education) in 1928, was named as İsmet Paşa Girls' Institute upon the recommendation by Swiss Omar Buyse. The institute began serving to five students in one of the buildings owned by Child Protection Agency in 1928 and the number of the students was twenty-eight at the end of the same education year. The institute began serving in its new building in 1930-1931. The design of the new building was made by the German origin architect Ernst Egli, and it was built by a Turkish firm. The school was managed by a French origin female principal, and by Turkish principal Mr. Münir Hayri from 1932. There were three departments in the institute during its first years: İsmet Paşa Girls' Institute, Girls' Technical Teachers' School and Girls' Evening Art School.

İsmet Paşa Girls' Institute, which serves as Zübeyde Hanım Vocational and Technical Anatolian High School today, was an eminent school in terms of contemporary women education in Turkey's educational history during the first years of Republic of Turkey. İsmet Paşa Girls' Institute was the first school for vocatinal and technical education of girls during the first years of 
republic. İsmet Paşa Girls' Institute, built in the most visited street in the capital city of the new state, drew attention via both its magnificent design and its modern vocational educational services towards girls.

The institute was appreciated thanks to the traditional fashion shows both inside and outside of the country. The school even organized a fashion show in Paris, considered as the capital of the fashion across the world and displayed the modernization process of Turkish women. The fact that foreign and Turkish teachers worked in this school and the fact that foreign principals administered the school during its first years were important in terms of showing that its teaching activities were at universal education standarts.

Republic of Turkey's founder, Mustafa Kemal Ataturk as well as senior people from foreign countries visited the school. In this context, it is an important situation for some foreign visitors to have the school built in their own country as an indicator of the admiration of the school, and that the representative of a developed country such as the USA closely involved with the school and reported the school-related features in the Republican period.

In this school, it is understood that it was attempted to grow Turkish women as good spouses, good teachers, contemporary mothers, individuals who developed culturally and had strong personality. Further, it was aimed at growing them as idealist, free, representative of the Republic and protectors the values of the Republic, as modern and exemplary individuals.

\section{Kaynakça / References}

Akın, M. (2011). Kız teknikeğitim öğretiminde bir örnek ankara olgunlaşma enstitüsüu. (Yüksek Lisans Tezi). Ankara Üniversitesi. Türk İnkılap Tarihi Enstitüsü.

Akşit, E. E. (2005). Kızların sessizliği kız enstitülerinin uzun tarihi. İletişim Yayınları, $144,146$.

Alpagut, L. (2005). Erken Cumhuriyet Döneminde Ankara'daki eğitim yapları. (Doktora Tezi). Hacettepe Üniversitesi SBE.

Alpagut, L. (2010). Erken Cumhuriyet döneminde kızların eğitimi için Ankara' da İki önemli yapı: İsmet Paşa Kız Enstitüsü ve Kız Lisesi. Mimarlk, 01.04.2018 tarihinde www.mimarlikdergisi.com/index.cfm?sayfa=mimarlik\&DergiSayi=365\&RecID=2289 adresinden erişilmiştir.

BCA, Fon Kodu: 301000, Kutu No: 261, Dosya Gömleği No: 762, Sıra No: 24, Tarih: 1938.11.03 
BCA, Fon Kodu: 301000, Kutu No: 261, Dosya Gömleği No: 762, Sıra No: 24, Tarih:17.05.1932

BCA, Fon Kodu: 30-18-01-02, Kutu No: 47, Dosya Gömleği No: 52, Sira No: 4, Tarih:17.05.1934

BCA, Fon Kodu: 30-18-02, Kutu No: 28, Dosya Gömleği No: 39, Sıra No: 9 Tarih:17.05.1932

Cevizliler, E., ve Cevizliler, N. (2004). Amerika Büyükelçisi Charles H. Sherrill'in Raporuyla İsmet Paşa Kız Enstitüsü (Ankara), Kazım Karabekir Eğitim Fakültesi Dergisi. (9). 181, 183, 184-185, 186.

Çocuklarımızı Nerelerde Okutmalıyı;; İsmet İnönü Kız Enstitüsü. (1936, 26 Ağustos). Ulus, 5.

Çocuklarınızı Nerelerde Okutmalısınız? III. İsmet Paşa kız Enstitüsü. (1936, 26 Ağustos). Ulus, 5.

Deskgram. (t.y). $\quad 01.09 .2019 \quad$ tarihinde https://deskgram.net/explore/tags/\%D9\%87\%D9\%86\%D8\%B1\%D8\%B3\%D8\%AA\%D8 \%A7\%D9\%86_\%D8\%AF\%D8\%AE\%D8\%AA\%D8\%B1\%D8\%A7\%D9\%86 adresinden erişilmiştir.

Gök, F. (1999). Kız Enstitüleri, Ev Kadını Yetiştiren Asri Bir Müessese, Yetmiş Beş Yılda Eğitim. Tarih Vakfi Yayınları, 242.

İsmet İnönü Kız Enstitüsü Yıllık Sergisi Açldı. (1935, 15 Haziran). Ulus, 4.

İsmet İnönü Kız Enstitüsünde Açılan Serim. (1935, 10 Nisan). Ulus, 5.

İsmet Paşa Kız Enstitüsünde Dikiş ve Biçki Atölyesinde Bir Sergi Açllyor. (1936, 4 Mayis). Ulus, 2.

İsmet Paşa Kız Enstitüsünde Dün Güzel Bir Sergi Açıldı. (1936, 5 Mayıs). Ulus, 5.

Karagöz, S. (2019). Cumhuriyet dönemi eğitimine yön veren yerli ve yabancı uzman raporları (1911-1927). Pegem Akademi, 304, 306.

Karagöz, S., Şanal, M. (2015). İkinci Meşrutiyet Dönemi Kadın Gözüyle Kadın Eğitimi. Uluslararası Sosyal Araştırmalar Dergisi. 8(39). 679, 680, 681.

Kılınç, M. (2007). Ankara Zübeyde Hanım Anadolu Kız Meslek Teknik ve Meslek Lisesi 1928-2006. (Yüksek Lisans Tezi). Niğde Üniversitesi. Sosyal Bilimler Enstitüsü. Niğde.

Kılınç, M. (2013). Türkiye'de Mesleki Teknik Eğitim Tarihi Gelişimi (1908-1986). (Doktora Tezi). Ankara Üniversitesi. Türk İnkılap Tarihi Enstitüsü. Ankara.

Kılınç, M. (2016). Türkiye'de Mesleki Teknik Eğitim Tarihi (1886-1986). Pegem Akademi, 234. 
Kılınç, M. (2017). Türkiye'de Mesleki Teknik Eğitimde Öncü Bir Kurum Ankara Zübeyde Hanım Anadolu Kız Meslek Teknik ve Meslek Lisesi 1928-2000. Pegem Akademi, 15-16, 39-41.

Kurtdaş, M. Ç. (2012). Osmanlıdan Cumhuriyete Modernleşme Sürecine Kısa Bir Bakış. Hikmet Yurdu, Düşünce Yorum Sosyal Bilimler Araştırma Dergisi. 5(9). 101114.

Maarif Vekaleti. (1939). Maarif Vekilliği Dergisi. (21-22). 169-171. Ankara.

Makki, H. (1985). Tarihe Bist Saleye İran. Altnnc Cilt. Amirkabir Yayınları, 157.

Melek Zade, E. (2013). Pahlevi Döneminde Kadınların Resmi Tarihçesine Bir Bakış.

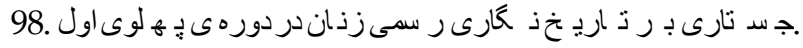

Münir, H. (1396, 1 Temmuz). Ǘç Mektep Üç Sergi. Ulus, 5.

Sezer, A. A. (2011). Ankara'da Modanın Öncüsü Bir Okul: İsmet Paşa Kız Enstitüsü. Cumhuriyet Tarihi Araştırmaları Dergisi Y1l 7. (14). 8.

Soroushiani, S., Daniel V., Shafei B. (2008). Vartan Hovanessian Architecture. Tehran:

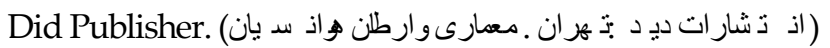

Wikimapia. (t.y). Iran. 01.09 .2019 tarihinde http://wikimapia.org/24449786/fa/\%D9\%87\%D9\%86\%D8\%B1\%D8\%B3\%D8\%AA\%D $8 \%$ A7\%D9\%86-

\%D8\%AF\%D8\%AE\%D8\%AA\%D8\%B1\%D8\%A7\%D9\%86-

\%D9\%85\%D8\%AC\%D8\%AA\%D9\%85\%D8\%B9-

\%D8\%AA\%D8\%B1\%D8\%A8\%DB\%8C\%D8\%AA\%DB\%8C-

\%D9\%85\%D8\%AA\%D9\%82\%DB\%8C\%D9\%86 adresinden erişilmiştir.

Yerli Malları Dolayısıyla İsmet Paşa Kız Enstitüsü Dün Güzel Bir Müsamere Verdi. (1935, 16 İkkanun). Ulus, 4.

Zübeyde Hanım Mesleki Teknik Lisesi. (t.y). Ansayfa. 01.04.2018 tarihinde http://zhkml.meb.k12.tr/meb_iys_dosyalar/06/01/118575/icerikler/okulumuzuntarihcesi_124604.html adresinden erişilmiştir. 
Cumhuriyet Dönemi Türk Kadınının Modernleşmesinde Öncü Bir Kurum: İsmet Paşa Kırz Enstitüsü Ankara (1928-1938)

\section{Ekler}

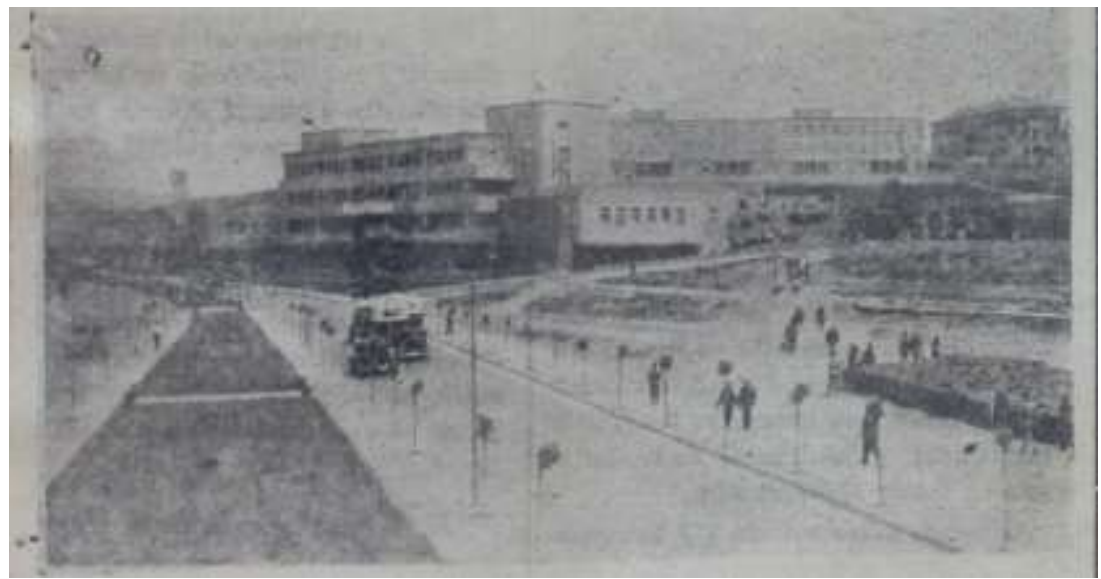

Ek 1. İsmet Paşa Kız Enstitüsünden Bir Görünüş ${ }^{6}$

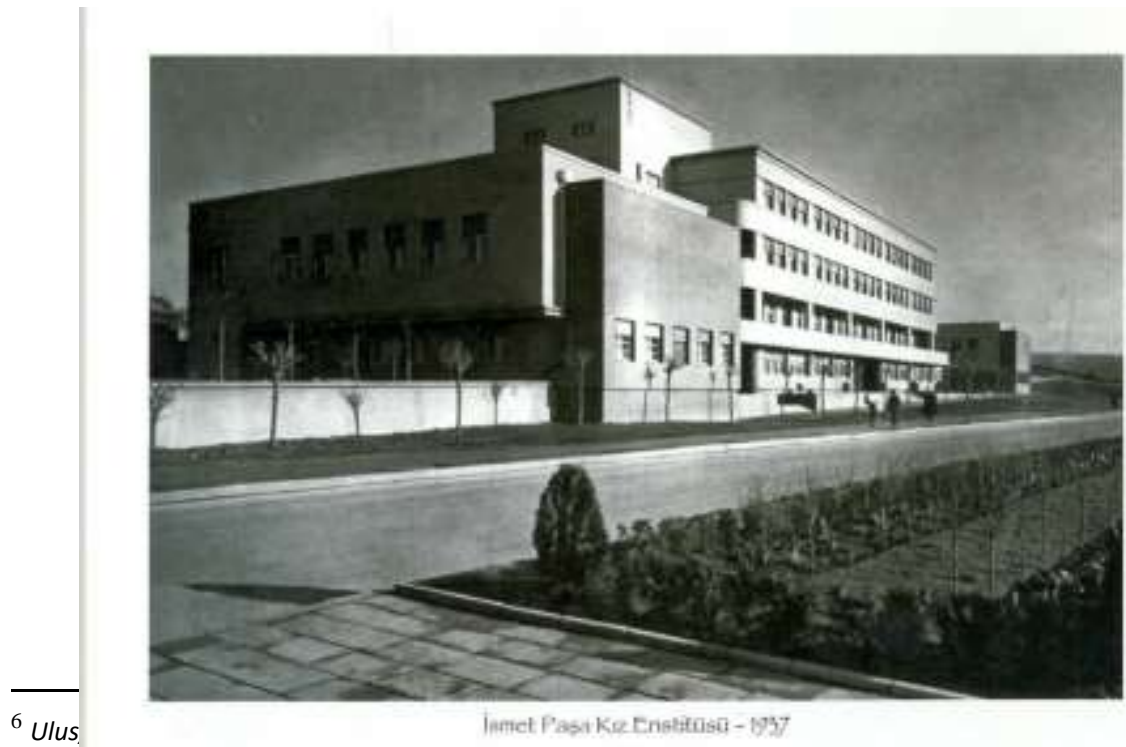




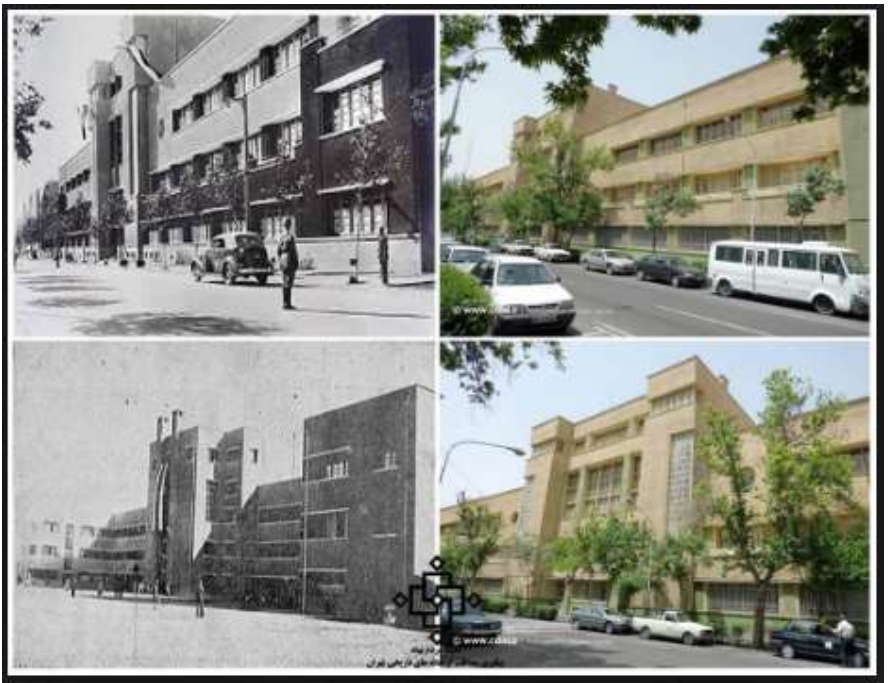

Ek 3. Mocteme-i Terbiyet-i Mottegin (Iran) ${ }^{8}$

${ }_{7}$ Mustafa Kılınç,_Ankara Zübeyde Hanım Anadolu Kız Meslek Teknik ve Meslek Lisesi 1928-2006, Niğde Üniversitesi, Sosyal Bilimler Enstitüsü, Yüksek Lisans Tezi, Niğde, 2007, s.134

${ }^{8} \underline{U R L} 4$ 


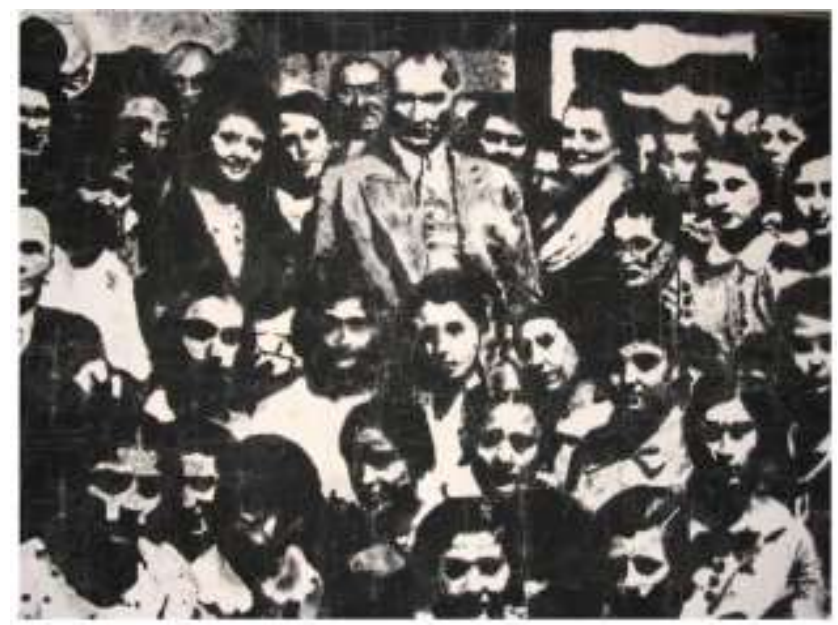

Ek 4. Atatürk'ün 04.06.1933 Yılında İsmet Paşa Kız Enstitüsü'nü Ziyareti ${ }^{9}$

\section{Kaynakça Bilgisi / Citation Information}

Doğan, A. ve Kılınç, M. (2020). Cumhuriyet dönemi Türk kadınının modernleşmesinde öncü bir kurum: İsmet Paşa Kız Enstitüsü Ankara (1928-1938). OPUS-Uluslararası Toplum Araştırmaları Dergisi, 16(29), 2371-2389. DOI: 10.26466/opus.767508

${ }^{9}$ Kılınc, age., s.133 